\title{
EFFECT OF APPLICTION OF YEAST AND SPRAYING WITH POTASSIUM AND SULPHUR ON GROWTH AND FRUITING OF WILLIAMS BANANAS
}

\author{
ROSHDY, KH. A. \\ Tropical fruits Res. Dept., Hort. Res. Inst., ARC, Giza , Egypt
}

(Manuscript received 10 January 2016)

\begin{abstract}
$\mathrm{T}$ his study was carried out during 2013/2014 and 2014/2015 seasons to examine the effect of single and combined soil applications of yeast at $200 \mathrm{~g}$./plant/year as well as spraying potassium sulphate and micronized sulphur each at $0.5 \%$ on growth and fruiting of Williams bananas grown under Beni- Suef Governorate climatic conditions. Single and combined soil application of yeast at 200g./plant/year as well as spraying potassium sulphate and micronized sulphur each at $0.5 \%$ were very effective in enhancing all growth aspects,yield and fruit characteristics relative to the check treatment. This promotion was substantially related to using yeast, potassium sulphate and micronized sulphur in descending order. Combined applications were more favourable than using each material alone in this respect. Four sprays of a mixture containing potassium sulphate and micronized sulphur each at $0.5 \%$ besides soil application of yeast once at $200 \mathrm{~g} . /$ plant/year were responsible for improving yield and fruit quality of Williams bananas grown under Beni- Suef Governorate climatic conditions.

Key words: Williams bananas, yeast, potassium sulphate and sulphur.
\end{abstract}

\section{INTRODUCTION}

Banana especiallay Williams Cv. is considered to be one of the important tropical fruits successfully grown under Egypt climatic conditions. Nowadays, many efforts have been established for finding out the best horticultural practices that enhancing yield and fruit quality.

Clean cultivation is greatly achieved by using yeast. It contains highe amounts of IAA, cytokinins, proteins, amino acids as Arginine, Histidine, Isoleiucine, Leucine, Lysine, Methionine, Cysteine, Phenylalanine, Tyrosine, Serine, Valine, Threonine, Tryptophan, vitamins namely vitamins $\mathrm{B}$, minerals such as $\mathrm{N}, \mathrm{P}$ and $\mathrm{K}$ according to Abou-Zaid, (1984) and Barnett et al, (1990).

Potassium activates 60 enzymes, water and nutrients transport, root growth,drought and salinity resistance, biosynthesis and translocation of sugars and regulating the opening and closing of stomata that are essential for photosynthesis and enhancing the tolerance of plants to disorders enfection Nijjar (1985). 
Using sulphur on banana orchards is not common or rare in Egypt, this is due to the application of sulphur free fertilizers, the reduction in the use of sulphur insecticides and fungicides and the readily leaching with irrigation water withoute compensation by external additions. Using sulphur achievies many merits such as enhancing building of proteins, enzymes and reducing soil pH and salinity Nijjar (1985).

Previous studies showed that using potassium Haohash and Abd El-Nasser, (2010); Abdallh, (2014); Ahmad et al, (2014) and Ibrahim and Al-wasfy, (2014), sulphur Ahmed, (2001); Hassan-Huda, (2014) and Abdallh,(2014) and Yeast Abd ElRahman,(2005); Badawy-Sabah,(2005); Badran and Mohamed, (2009); Merwad,(2011); Mahmoud, (2012) and Oraby, (2013) was very potent in stimulating growth, nutritional status of the trees as well as promoting yield and fruit quality.

This study was established for examine the effect of single and combined applications of yeast, potassium and sulphur on growth aspects, nutritional status of the plants, yield and fruit quality of Williams banana plants grown under Beni- Suef Governorate climatic conditions.

\section{MATERIALS AND METHODS}

This study was carried out during 2013/2014 (third ratoons) and 2014/2015(fourth ratoons) seasons on Williams banana planted in a private orchard situated at Beba district, Beni- Suef Governorate. The chosen Williams banana plants were subjected to the normal horticultural practices that were carried out in the groove except those dealing with potassium and sulphur fertilization and using biofertilization. The holes were planted at a spacing of $3.5 \times 3.5 \mathrm{~m}$., surface irrigation was practiced. Soil analysis was done according to Wilde et al, (1985)and the obtained data are shown in Table(1)

Table 1. Analysis of the tested orchard soil.

\begin{tabular}{|l|l|}
\hline \multicolumn{1}{|c|}{ characters } & values \\
\hline Particle size distribution: & \\
Sand \% & 8.7 \\
Silt \% & 55.3 \\
Clay \% & 36.0 \\
Texture & Silty clay \\
PH $(1: 2.5$ extract) & 7.29 \\
EC (1:2.5 extract)mmos $/ 1 \mathrm{~cm} / 25^{\circ} \mathrm{C}$ & 0.74 \\
O.M \% & 2.09 \\
Caco $\%$ & 1.80 \\
Total N \% & 0.11 \\
Available P (ppm,Olsen) & 4.22 \\
Available K (ppm,ammonium acetate) & 310 \\
Available S (ppm) & 3.11 \\
Available EDTA extractable micronutrients(ppm) & \\
Zn & 11.49 \\
Fe & 9.11 \\
Mn & 10.1 \\
Cu & 1.05 \\
\hline
\end{tabular}


This study included the following seven treatments:

1) Control plants (untreated plants).

2) Using yeast as a soil treatment at $200 \mathrm{~g}$./plant/year

3) Using potassium sulphate $\left(48.52 \% \mathrm{~K}_{2} \mathrm{O}\right)$ as a spray at $0.5 \%$.

4) Using micronized sulphur as a spray at $0.5 \%$.

5) Using yeast at $200 \mathrm{~g} . /$ plant+ potassium sulphate at $0.5 \%$.

6) Using yeast at $200 \mathrm{~g} . /$ plant+ micronized sulphur at $0.5 \%$.

7) Using all together at the samed concentrations.

Each treatment was replicated three times (three holes /replicate).Randomized complete blocks design (RCBD) was followed. Data in Table(2)shows chemical analysis of yeast extract according to Abou-Zaid, (1984) Yeast as a biofertilizer (each 1g. contains 12000 yeast cells) Barnett et al., (1990) was activated before application by using sugar solution at $5 \%$.The media was left at $30^{\circ} \mathrm{C}$ for six hours and subjected to freezing and thawing for disruption of yeast tissues and releasing their bio constituents directly before using. The two materials namely potassium sulphate and micronized sulphur were sprayed four times at the first week of April, June, August and October during both seasons. Soil application of yeast was carried out once at the first week of April. Triton B as a wetting agent at $0.05 \%$ was added to all solution and spraying was done till runoff.

\section{The following parameters were recorded:}

\section{1)vegetative growth characters.}

Height and girth of pseudostem (cm.), total number of emerged leaves per plant and number of grean leaves at bunch shooting were recorded. Leaf area $(m)^{2}$ using the third full sized leaf (from the top)was calculated according to Murry, (1960). (Leaf area $=$ lenth $\mathrm{x}$ width $\times 0.8$ ). 
Table 2. chemical analysis of yeast extract.

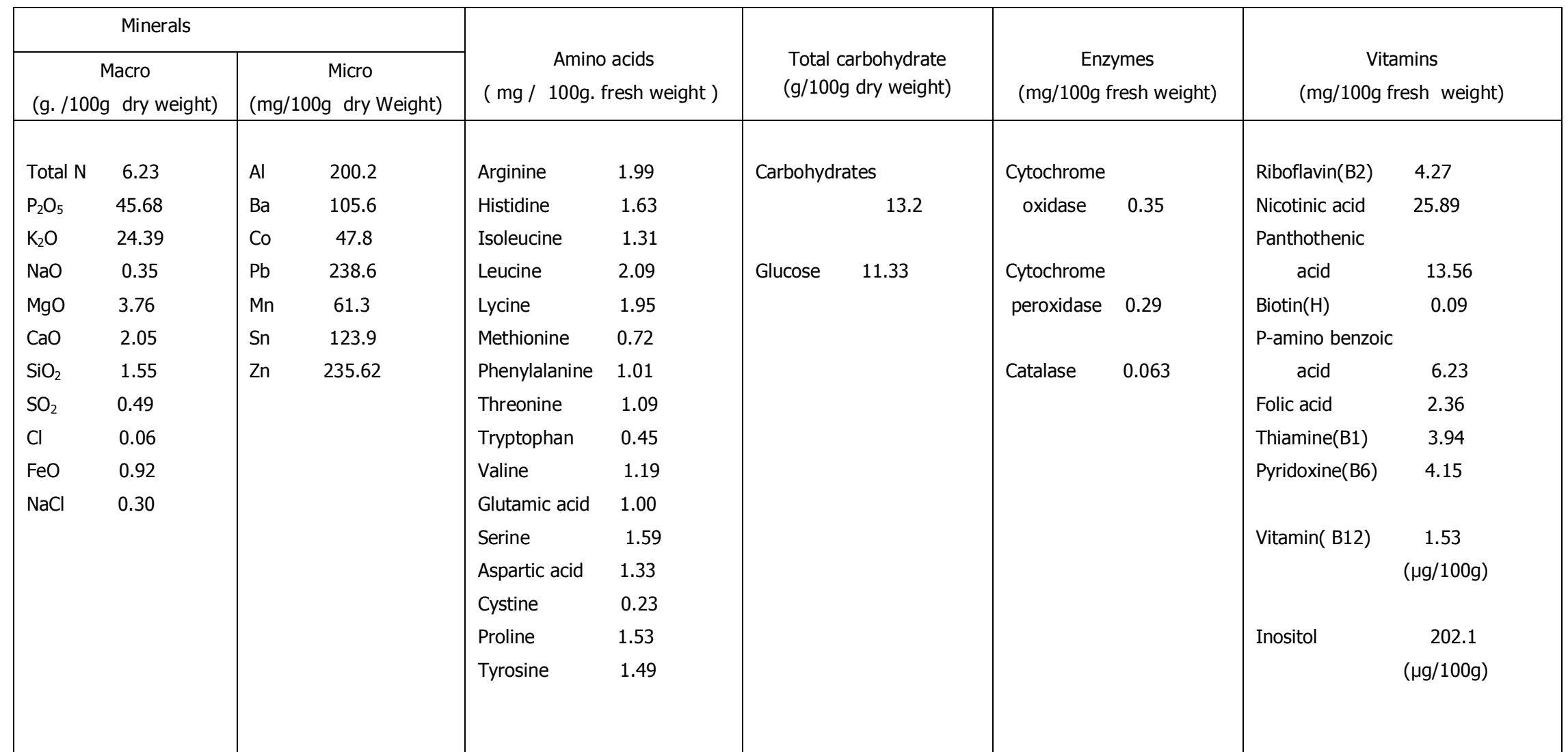




\section{2) Flowering and bunch characteristics.}

The Period to bunch shooting, period to harvest and cropping cycle were recorded. The bunches were harvested at bunch maturation stage using angulations criterion of finger as reported by Abd El-Naby, (1988). At harvest, bunch weight (kg), number of hands per bunch and hands weight $(\mathrm{kg})$ were determined.

\section{3) Physical and chemical characteristics of the fruits.}

They included length and diameter of fingers (cm), finger weight(g.), percentages of pulp to peel weights, T.s.s. \%, total acidity (as g. malic acid /100g.pulp) as well as total, reducing and non-reducing sugars A.O.A.C.,(2000).

The obtained data were tabulated and statistically analyzed according to Snedecor and Cochran, (1990), treatments means were compared by using New L.S.D test at $5 \%$.

\section{RESULTS AND DISCUSSION}

\section{1)Vegetative growth characters.}

Data in table (3) show that treating Williams bananas with yeast as a soil application at $200 \mathrm{~g} /$ plant/year as well as spraying potassium sulphate and micronized sulphur each at $0.5 \%$ significantly was accompanied with stimulated the five growth characters namely height and girth of pseudostem, total number of leaves per plant, number of green leaves at bunch shooting and leaf area comparing to the control treatment.

The promotion was significantly associated with using yeast, potassium sulphate and sulphur in descending order. In general combined application of the three investigated materials was significantly superior than using each material alone. The best double application was using yeast as soil addition and spraying potassium sulphate at $0.5 \%$. The maximum values of height $(241.7$ and $244.5 \mathrm{~cm})$ and girth $(83.3$ and $87.0 \mathrm{~cm}$ ) of pseudostem, total number of leaves / plant(27.4 and 28.3), number of green leaves at bunch shooting / plant(15.6 and 16.4)and leaf area(2.62 and 2.66m²) were recorded on the plants that received one addition of yeast at $200 \mathrm{~g} . /$ plant/year and four sprays of a mixture of potassium sulphate and sulphur each at $0.5 \%$. The lowest values were recorded on the control plants (untreated plants).

These results concerning the promoting effect of yeast on growth characters were in harmony with those obtained by Mohamed and Badran, (2009) and Oraby, (2013). 
Table 3. Effect of application yeast and spraying potassium sulphate and sulphur on some growth characters of Williams bananas plants during 2013/2014 and 2014/2015 seasons.

\begin{tabular}{|c|c|c|c|c|c|c|c|c|c|c|}
\hline \multirow[t]{2}{*}{ Treatments } & \multicolumn{2}{|c|}{$\begin{array}{l}\text { Pseudostem } \\
\text { height }\end{array}$} & \multicolumn{2}{|c|}{$\begin{array}{l}\text { Pseudostem } \\
\text { girth }\end{array}$} & \multicolumn{2}{|c|}{$\begin{array}{l}\text { Total number of } \\
\text { Leaves/plant }\end{array}$} & \multicolumn{2}{|c|}{$\begin{array}{l}\text { No. of green } \\
\text { leaves at bunch } \\
\text { shooting }\end{array}$} & \multicolumn{2}{|c|}{ Leaf area $\left(\mathrm{m}^{2}\right)$} \\
\hline & $\begin{array}{l}2013 / \\
2014\end{array}$ & $\begin{array}{l}2014 / \\
2015\end{array}$ & $\begin{array}{l}2013 / \\
2014\end{array}$ & $\begin{array}{l}2014 / \\
2015\end{array}$ & $\begin{array}{l}2013 / \\
2014\end{array}$ & $\begin{array}{l}2014 / \\
2015\end{array}$ & $\begin{array}{l}2013 / \\
2014\end{array}$ & $\begin{array}{l}2014 / \\
2015\end{array}$ & $\begin{array}{l}2013 / \\
2014\end{array}$ & $\begin{array}{l}2014 / \\
2015\end{array}$ \\
\hline Control ( untreated plants ) & 210.0 & 211.0 & 71.3 & 71.9 & 23.0 & 22.0 & 11.0 & 12.0 & 2.29 & 2.28 \\
\hline Using yeast at $200 \mathrm{~g} . /$ plant & 228.3 & 229.9 & 78.3 & 79.0 & 25.3 & 25.3 & 13.0 & 15.2 & 2.47 & 2.50 \\
\hline Using $\mathrm{K}_{2} \mathrm{SO}_{4}$ at $0.5 \%$ & 222.3 & 223.3 & 75.0 & 76.0 & 25.1 & 24.1 & 12.0 & 14.2 & 2.40 & 2.41 \\
\hline Using $\mathrm{S}$ at $0.5 \%$ & 216.3 & 217.3 & 73.0 & 74.0 & 24.1 & 23.1 & 11.9 & 13.1 & 2.34 & 2.33 \\
\hline Using yeast $+\mathrm{K}_{2} \mathrm{SO}_{4}$ & 239.3 & 241.3 & 82.0 & 85.0 & 26.3 & 27.0 & 14.6 & 15.3 & 2.57 & 2.60 \\
\hline Using yeast $+\mathrm{S}$ & 235.3 & 236.3 & 80.0 & 82.3 & 26.0 & 26.4 & 14.0 & 15.2 & 2.52 & 2.55 \\
\hline Using yeast $+\mathrm{K}_{2} \mathrm{SO}_{4}+\mathrm{S}$ & 241.7 & 244.5 & 83.3 & 87.0 & 27.4 & 28.3 & 15.6 & 16.4 & 2.62 & 2.66 \\
\hline New L.S.D. at $5 \%$ & 1.44 & 1.51 & 1.01 & 1.04 & 1.0 & 1.0 & 1.0 & 1.0 & 0.04 & 0.04 \\
\hline
\end{tabular}


These results regarding the effect of potassium on enhancing growth characters are in agreement with those obtained by Haohash and Abd El- Nasser, (2010) and Ibrahim and Al-Wasfy, (2014).

The results of Ahmed, (2001) and Abdallh, (2014) emphasized the present effect of sulphur on growth characters.

\section{2) Flowering and bunch characteristics.}

Data in table (4) obviously reveal that the period to bunch shooting, periods to harvest and cropping cycle were significantly advanced with using yeast via soil addition, potassium sulphate and sulphur at $0.5 \%$ either applied alone or in different combinations rather than control (untreated plants).Using yeast was significantly superior than using the other two materials. Potassium sulphate occupied the second position in this respect. A significant enhancement in these periods was observed due to using combinations over the using of single method. The plants received all nutrients gave a great advancement in all periods (bunch shooting, harvesting and cropping cycle). Under such the promised treatment the periods to (bunch shooting was $386 \& 385$ days and harvesting 110 \&110days)for both seasons, respectively.

days, harvesting 121 and 120 days and cropping cycle 541 and 538 days for both seasons, respectively.

These results are in concordance with those obtained by Merwad, (2011) who worked on yeast, Ibrahim and Al-Wasfy, (2014) who worked on potassium and Abdallh, (2014) who worked on sulphur.

In addition, it is noticed from the obtained data in table (4) that treating Williams bananas to yeast once as soil addition and spraying potassium sulphate and sulphur significantly was accompanied with improving bunch and hands weights and had no significant effect on number of hands/bunch when comparing with the control plants. Using yeast, potassium sulphate and sulphur in descending order was significantly very effective in improving bunch and hands weights. The increase in bunch weight did not correlate with the increase in number of hands/bunch because this character(number of hands/bunch) is a genetic feature which is associated with the type, clone or variety, while the increase in bunch weight correlates with the increase in hands weight in this study. Combined applications were favourable than using each material alone in this respect. The maximum values were recorded on the plants that received all materials together. Under such the promised treatment bunch weight reached(30.1 and $31.3 \mathrm{~kg})$ compared with bunch weight of control treatment plants that reached $(24.1$ and $23.9 \mathrm{~kg})$. The percentage of increment on bunch weight of such the promising treatment over the control treatment reached ( $24.9 \%$ and $31 \%$ )for both seasons, respectively, as well as under that the promised treatment hand weight reached( $2.37 \mathrm{and} 2.48 \mathrm{~kg}$ ) compared with hand weight of control plants that reached $(2.01$ and $1.98 \mathrm{~kg}$ ) for both seasons, respectively. 
Table 4. Effect of application yeast and spraying potassium sulphate and sulphur on Flowering and bunch characteristics.

\begin{tabular}{|c|c|c|c|c|c|c|c|c|c|c|c|c|}
\hline \multirow[t]{2}{*}{ Treatments } & \multicolumn{2}{|c|}{$\begin{array}{c}\text { Period to } \\
\text { Bunch } \\
\text { Shooting (day) }\end{array}$} & \multicolumn{2}{|c|}{$\begin{array}{c}\text { Period to } \\
\text { Harvest(day) }\end{array}$} & \multicolumn{2}{|c|}{$\begin{array}{l}\text { Cropping } \\
\text { Cycle(day) }\end{array}$} & \multicolumn{2}{|c|}{$\begin{array}{c}\text { Bunch } \\
\text { Weight(kg.) }\end{array}$} & \multicolumn{2}{|c|}{$\begin{array}{c}\text { Number of } \\
\text { Hands/bunch }\end{array}$} & \multicolumn{2}{|c|}{$\begin{array}{c}\text { Hand } \\
\text { Weight(kg.) }\end{array}$} \\
\hline & $\begin{array}{l}2013 / \\
2014\end{array}$ & $\begin{array}{l}2014 / \\
2015\end{array}$ & $\begin{array}{l}2013 / \\
2014\end{array}$ & $\begin{array}{l}2014 / \\
2015\end{array}$ & $\begin{array}{l}2013 / \\
2014\end{array}$ & $\begin{array}{l}2014 / \\
2015\end{array}$ & $\begin{array}{l}2013 / \\
2014\end{array}$ & $\begin{array}{l}2014 / \\
2015\end{array}$ & $\begin{array}{l}2013 / \\
2014\end{array}$ & $\begin{array}{l}2014 / \\
2015\end{array}$ & $\begin{array}{l}2013 / \\
2014\end{array}$ & $\begin{array}{l}2014 / \\
2015\end{array}$ \\
\hline Control ( untreated plants ) & 420.0 & 418.0 & 121.0 & 120.0 & 541.0 & 538.0 & 24.1 & 23.9 & 12.0 & 12.1 & 2.01 & 1.98 \\
\hline Using yeast at $200 \mathrm{~g}$. / plant & 396.0 & 395.0 & 114.0 & 113.0 & 510.0 & 508.0 & 27.3 & 27.5 & 12.4 & 12.5 & 2.20 & 2.20 \\
\hline Using $\mathrm{K}_{2} \mathrm{SO}_{4}$ at $0.5 \%$ & 401.0 & 400.0 & 116.0 & 115.0 & 517.0 & 515.0 & 26.3 & 26.5 & 12.3 & 12.4 & 2.14 & 2.14 \\
\hline Using $\mathrm{S}$ at $0.5 \%$ & 411.0 & 410.0 & 118.0 & 117.5 & 529.0 & 527.0 & 25.2 & 25.3 & 12.2 & 12.2 & 2.07 & 2.07 \\
\hline Using yeast $+\mathrm{K}_{2} \mathrm{SO}_{4}$ & 390.0 & 390.0 & 111.0 & 111.0 & 501.0 & 501.0 & 29.0 & 30.0 & 12.6 & 12.6 & 2.30 & 2.38 \\
\hline Using yeast $+\mathrm{S}$ & 393.0 & 394.0 & 112.0 & 112.0 & 505.0 & 506.0 & 28.2 & 28.9 & 12.5 & 12.6 & 2.26 & 2.29 \\
\hline Using yeast $+\mathrm{K}_{2} \mathrm{SO}_{4}+\mathrm{S}$ & 386.0 & 385.0 & 110.0 & 110.0 & 496.0 & 495.0 & 30.1 & 31.3 & 12.7 & 12.6 & 2.37 & 2.48 \\
\hline New L.S.D. at $5 \%$ & 1.50 & 1.51 & 1.9 & 1.8 & 2.1 & 2.2 & 1.0 & 1.1 & N.S & N.S & 0.06 & 0.05 \\
\hline
\end{tabular}


Cropping cycle of the plants that received all materials was (496 and 495 days) during both seasons, respectively. The great delaying in these periods was recorded in control treatment (untreated plants) to bunch shooting was 420 and 418

These results concerning the promoting effect of yeast on bunch characterictics were in harmony with those obtained by Merwad, 2011).

These results regarding the effect of potassium on enhancing bunch characteristics are in agreement with those obtained by Ibrahim and Al- Wasfy, (2014).

The results of Abdallh, (2014) emphasized the present effect of sulphur on bunch characteristics.

\section{3) Physical and chemical characteristics of the fruits.}

It is worth to mention from the data in tables (5\&6) that supplying Williams banana plants with yeast once as soil addition and spraying potassium sulphate and sulphur each at $0.5 \%$ significantly was very effective in improving fruit.

quality in terms of increasing weight, length and width of finger, pulp weight\%, T.s.s.\%, total and reducing sugars and decreasing fruit peel weight $\%$ and total acidityrelative to the check treatment. The promotion on fruit quality was significantly associated with using yeast, potassium sulphate and sulphur in descending order. Combined applications were superior than using each material alone in improving fruit quality. The best results with regard to fruit quality were obtained due to treating the plants with all materials together, the untreated plants gave unacceptable fruit quality as it is clear from the data in Tables $(5 \& 6)$. The studied treatments had nosignificant effect on the percentage of non- reducing sugars. All these results were true for both seasons.

The promoting effect on growth traits, flowering, yield and fruit quality due to application of yeast might be attributed to its highe content of carbohydrate, amino acids, vitamins, enzymes and minerals Abou-Zaid, (1984) and Barnett et al, (1990) that was surely reflected on enhancing cell division and cell enlargement which led to stimulating growth characters, advancing of flowering, increasing yield and improving fruit quality.

Potassium has important roles in enhancing the tolerance of plant to drought and salinity, regulating the opening and closing of stomata that are essential for photosynthesis and enhancing the tolerance of plants to disorders enfection Nijjar (1985), enhancing the biosynthesis and translocation of sugars, activate a large number of enzymes, water and nutrients transport and root growth that was surely reflected on stimulating the growth, advancing of flowering, increasing of yield and improvement fruit quality. 
Table 5. Effect of application yeast and spraying potassium sulphate \& sulphur on Physical fruits characteristics.

\begin{tabular}{|c|c|c|c|c|c|c|c|c|c|c|}
\hline \multirow{2}{*}{ Treatments } & \multicolumn{2}{|c|}{$\begin{array}{c}\text { Finger weight } \\
\text { (g. ) }\end{array}$} & \multicolumn{2}{|c|}{$\begin{array}{l}\text { Finger length } \\
(\mathrm{cm} .)\end{array}$} & \multicolumn{2}{|c|}{$\begin{array}{l}\text { Finger width } \\
\qquad(\mathrm{cm} .)\end{array}$} & \multicolumn{2}{|c|}{$\begin{array}{l}\text { Fruit pulp } \\
\text { Weight \% }\end{array}$} & \multicolumn{2}{|c|}{$\begin{array}{l}\text { Fruit peel } \\
\text { Weight \% }\end{array}$} \\
\hline & $\begin{array}{l}2013 / \\
2014\end{array}$ & $\begin{array}{l}2014 / \\
2015\end{array}$ & $\begin{array}{l}2013 / \\
2014\end{array}$ & $\begin{array}{l}2014 / \\
2015\end{array}$ & $\begin{array}{l}2013 / \\
2014\end{array}$ & $\begin{array}{l}2014 / \\
2015\end{array}$ & $\begin{array}{l}2013 / \\
2014\end{array}$ & $\begin{array}{l}2014 / \\
2015\end{array}$ & $\begin{array}{l}2013 / \\
2014\end{array}$ & $\begin{array}{l}2014 / \\
2015\end{array}$ \\
\hline Control ( untreated plants ) & 101.00 & 100.11 & 19.61 & 19.71 & 3.19 & 3.41 & 67.83 & 67.90 & 32.17 & 32.10 \\
\hline Using yeast at $200 \mathrm{~g} . /$ plant & 103.61 & 103.97 & 21.64 & 21.74 & 4.15 & 4.30 & 69.43 & 69.50 & 30.57 & 30.50 \\
\hline Using $\mathrm{K}_{2} \mathrm{SO}_{4}$ at $0.5 \%$ & 103.00 & 102.22 & 20.46 & 21.05 & 3.85 & 4.01 & 68.94 & 69.00 & 31.06 & 31.00 \\
\hline Using $\mathrm{S}$ at $0.5 \%$ & 101.91 & 101.00 & 20.11 & 20.20 & 3.55 & 3.72 & 68.33 & 68.41 & 31.97 & 31.59 \\
\hline Using yeast $+\mathrm{K}_{2} \mathrm{SO}_{4}$ & 104.59 & 104.56 & 22.85 & 22.96 & 4.29 & 4.61 & 71.71 & 71.80 & 28.29 & 28.20 \\
\hline Using yeast $+\mathrm{S}$ & 104.21 & 104.00 & 22.18 & 22.28 & 4.50 & 4.60 & 71.21 & 71.30 & 28.79 & 28.70 \\
\hline Using yeast $+\mathrm{K}_{2} \mathrm{SO}_{4}+\mathrm{S}$ & 105.99 & 105.64 & 23.31 & 23.49 & 4.90 & 4.97 & 72.10 & 72.18 & 27.90 & 27.82 \\
\hline New L.S.D. at $5 \%$ & 0.51 & 0.47 & 0.45 & 0.48 & 0.31 & 0.29 & 0.36 & 0.35 & 0.40 & 0.41 \\
\hline
\end{tabular}


Table 6. Effect of application yeast and spraying potassium sulphate and sulphur on some chemical characteristics of the fruits.

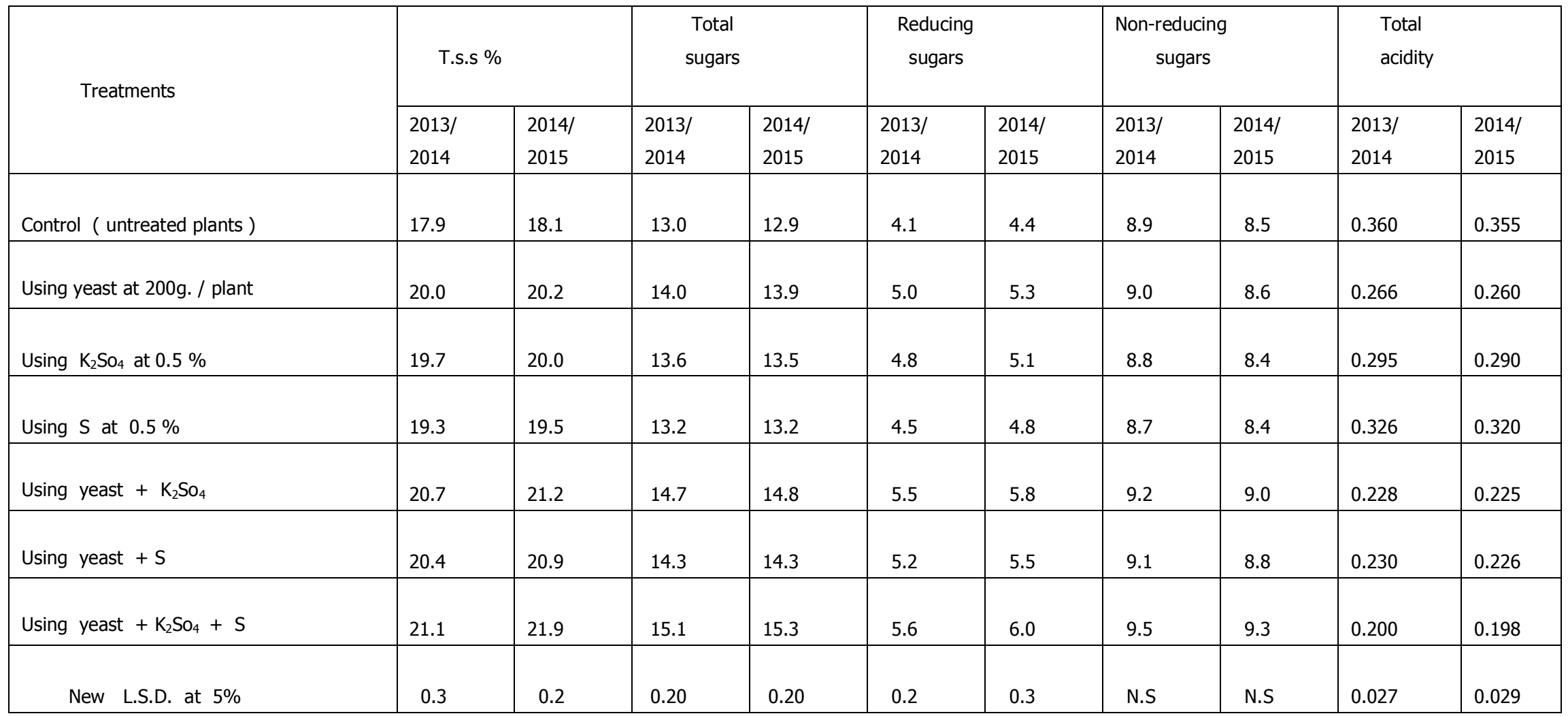


The positive action of sulphur on enhancing the biosynthesis of amino acids, enzymes and hormones and reducing soil pH and salinity Nijjar, (1985) could explain the obtained results as stimulating growth characters, advancing of flowering, increasing of yield and improving of fruit quality.

\section{CONCLUSION}

Carrying out one application of yeast at 200g./plant/year besides four sprays of a mixture of potassium sulphate and micronized sulphur each at $0.5 \%$ resulted in improving growth, yield and fruit quality of Williams banana plants grown under BeniSuef Governorate climatic conditions.

\section{REFERENCES}

1. Abdalla, A.A. 2014. Attempts for alleviating the adverse effects of soil and irrigation of Valencia orange.Ph.D.Thesis Fac.of Agric. Al-Azhar Univ.Egypt.

2. Abd El-Aal, A.M.K.; Ahmed, F.F. and Mahmoud, Kh.M.H. 2012. Partial replacement of chemical $\mathrm{N}$ fertilizers in Balady mandarin orchards through application of extracts of yeast, seaweed and farmyard manure. Minia J. of Agric.Res.\&Develop.32(1):129 - 148

3. Abd El-Naby,S.K.M. 1988. Studies of growth habits, flowering and fruiting of Poyo banana.M.Sc.Thesis Fac. of Agric.Al-Azhar Univ.Egypt.

4. Abd El-Rahman,M.M.A. 2005. Influence of varying number of ratoons as well as some antioxidants and Biofertilization treatments on growth and fruiting of Grand Naine banana growth under middle Egypt conditions. M.Sc.Thesis Fac. of Agric.Minia Univ. Egypt.

5. Abou-Zaid,M. 1984. Biochemical studies on fodder yeast. Ph. D. Thesis Fac. of Agric. Cairo Univ. Egypt.

6. Ahmed,A.M. 2001. Studies for controlling malformation and improving yield and fruit quality of Hindy bisiryana and mangoes by using yeast, ascorbic acid and sulphur.Minia J.of Agric.Res.\&Develop.(21)2 pp. 219 - 233

7. Ahmed,F.F.; Ali, A.H.S.; Sayed, E.S. and Sayed-Ola, M.O. 2014. Using some amino acids enriched with certain nutrients for improving productivity of El-Saidy date palms. World Rural obsrvations 6(2):20 - 27 Ahmed-Samah, O.O. 2011. Effect of yeast and effective microorganisms $\left(E_{1}\right)$ application on yield and fruit characteristics of Bartamuda date palm under Aswan climatic conditions. M. Sc. Thesis Fac. of Agric.Assiut Univ.

8. Association of Official Agricultural Chemists (A.O.A.C.) 2000. Official Methods of Analysis $1^{\text {th }}$ Ed. Published by A.O.A.C. Washington, D.C.(U.S.A.)pp.490 - 510. 
9. Badawy-Sabah, M. 2005. Histological effects of yeast and kinetin application on fruit characteristics and fruit growth stages of Balady mandarin cultivar. Ph.D.Thesis Fac. of Agric. Assiut Univ.

10. Badran, M.A.F. and Mohamed, A.Y. 2009. Response Williams bananas plants to application of EM and yeast. Egypt J. Agric.Res.87(1):129-141

11. Barnett, J.A.; Payne, R.W. and Yarrow, D. 1990.Yeast characteristics and identification. Cambridge Univ. Press, London pp999.

12. Haohash, M.M. and Abd El-Nasser, G. 2010.Impact of spraying the date palm Khalas $\mathrm{CV}$. bunches with potassium and boron on fruit set,fruit quality and nutrient content. Aust. J. Basic Applied Sci.4(9):4164 - 4172

13. Hassan-Huda, M.I. 2014. Impact of effective microorganisms and amino acids enriched with some nutrients on growth and fruiting of Valencia orange trees. Ph. D. Thesis Fac. of Agric. Minia Univ. Egypt.

14. Ibrahim, H.I.M. and Al-Wasfy, M.M. 2014.The promotive impact of using Silicon and Selenium with Potassium and boron on fruiting of Valencia orange trees grown under Minia region conditions.World Rural obsrvations 6(2):28-36

15. Mahmoud,Kh.M.H. 2012.Reducing inorganic nitrogen fertilizer in Balady mandarin orchards through application of extracts of yeast, seaweed and farmyard manure.Ph.D. Thesis Fac. of Agric. Minia Univ. Egypt.

16. Merwad,M.M.A. 2011.Effect of nitrogen sources, rates. some biostimulants and antioxidants on growth \& productivity of banana plants. Ph.D. Thesis Fac.of Agric. Zagazig Univ. Egypt.

17. Murry,D.B. 1960.Deficiency symptoms of the major elements in the banana.Trop.Agric.Trim.36:100-107.

18. Nijjar, G.S. 1985.Nutrition of Fruit Trees. Mrs Usha Raj. Kumar, for Kalyane Publisher,New Delhi India pp.10-70.

19. Oraby,A.A.F. 2013. Partial replacement of inorganic nitrogen fertilizer by spraying some vitamins,yeast and Seaweed extract in Ewaise mango orchard under Upper Egypt coditions.M.Sc.Thesis Fac. of Agric. Minia Univ. Egypt.

20. Summer. 1985. Diagnosis and Recommendation Integrated System (DRIS)as a guide to orchard fertilization.Hort.Abst. 55(8):7502.

21. Snidecor,C.W. and Cochran,W.G. 1990. Statistical methods $7^{\text {th }}$ Ed.The Iowa state Univ.press Amer.IowaUSA p.593.

22. Wilde,S.A.; Cory,R.B.; Layer,J.G. and Voigt,G.K. 1985. Soil and Plant Analysis for tree Culture Oxford and IBH publishing Co., New Delhi, India pp.94-105. 


\title{
تأثثير اضافة الخميرة والرش بالبوتاسيوم والكبريت
}

\section{على النمو والإثمار فى الموز الوليامز}

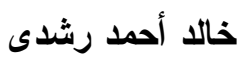

قسم بحوث الفاكهة الاستو ائية- معهد بحوث البساتين - مركز البحوث الزراعية - الجيزة- دصر

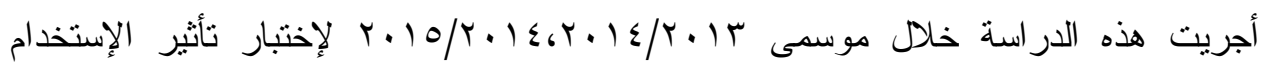

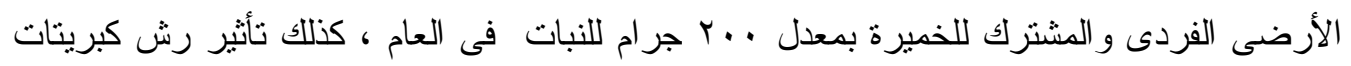

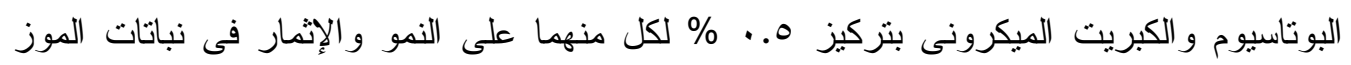

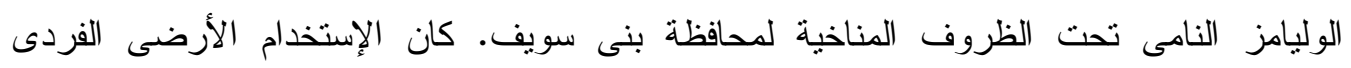

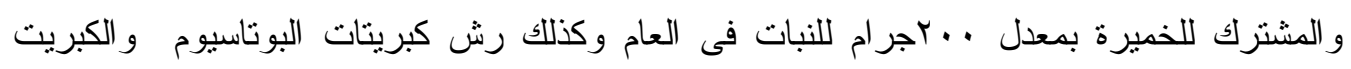
الميكرونى بتركيز ه. •. \% لكل منهما فعالا جدا فى تحسين جميع خصائص النمو الخضرى وكمية المحصول وخصائص الثمار وذلك بالمقارنة بمعاملة الكنترول وكان هذا التحسن منو افقا مع استخدام

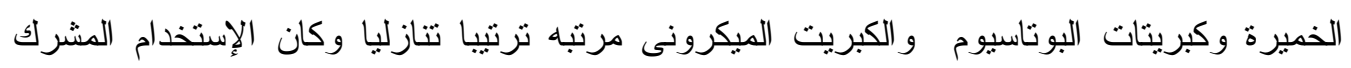
أفضل من الإستخدام الفردى لهذه المو اد.

لأجل تحسين كمية المحصول وخصائص الجودة للثمار فى نباتات المو الوليامز النامى تحت

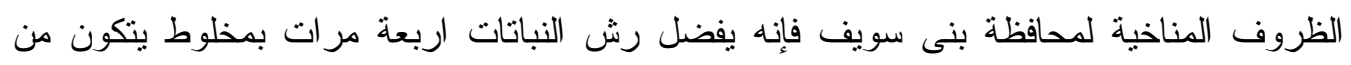

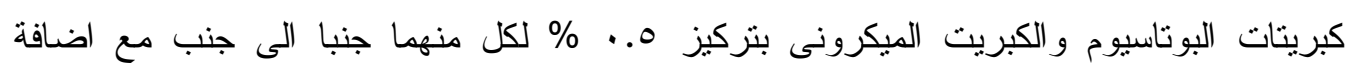
الخميرة الى التزبة مرة واحدة بمعدل .اجر ام للنبات. 